\title{
Intraoperative transfusion practice in burned children in a university hospital over four years: a retrospective analysis
}

Eva Wittenmeier ${ }^{1 *} \mathbb{D}$, Astor Katharina ${ }^{2}$, Irene Schmidtmann³, Eva-Verena Griemert', Marc Kriege', Tatjana König ${ }^{4}$ and Pirlich Nina ${ }^{1}$

\begin{abstract}
Background: Patient blood management programs should be applied to the pediatric population, but little is known about the current transfusion practice of pediatric burn injury patients. This retrospective study was performed to evaluate the practice of red blood cell (RBC) transfusion in children with burn injury, their predictive factors, and adherence to the German transfusion guideline.

Methods: We reviewed the RBC transfusion practice of all children younger than 8 years with burn injury who were operated during a four-year period in a German university medical center. We analyzed the data associated with transfusion and guideline conformity of transfusion triggers for RBCs from the beginning to the end of hospital stay using logistic regression.

Results: During the four-year period, 138 children (median age 21 months, minimum-maximum 9-101 months) with burn injury needed surgery, 31 children were transfused with RBCs. During their hospital stay, the median hemoglobin concentrations $(\mathrm{Hb})$ of transfused and non-transfused children were $8 \mathrm{~g} / \mathrm{dL}(6.3-11.3 \mathrm{~g} / \mathrm{dL})$ and 10.7 (7$13.8 \mathrm{~g} / \mathrm{dL})$, respectively. Total body surface area burned (TBSA) $(\mathrm{OR}=1.17$ per \% TBSA, 95\% $\mathrm{Cl}=[1.05 ; 1.30], p=$ $0.0056)$, length of surgery $(\mathrm{OR}=1.016$ per minute, $95 \% \mathrm{Cl}=[1.003 ; 1.028], p=0.0150)$, and $\mathrm{Hb}(\mathrm{OR}=0.48$ per $1 \mathrm{~g} / \mathrm{dl}$ in $\mathrm{Hb}, 95 \% \mathrm{Cl}=[0.24 ; 0.95], p=0.0343$ ) were associated with transfusion while other factors (age, gender, ASA, and catecholamines) did not show notable association. Length of stay was mainly influenced by TSBA $(+1.38$ days per $\%, p<0.0001)$, age (+ 0.21 days per month, $p=0.0206)$, and administering of catecholamines $(+14.3$ days, $p=$ 0.0118 ), but not by RBC transfusion. The decision to transfuse was in $23 \%$ too restrictive and in $74 \%$ too liberal according to the German guidelines.

Conclusions: Amount of TBSA, length of surgery, and Hb influenced the RBC transfusion rate in burned children. However, age and length of stay were not affected by transfusion of RBCs. In clinical practice of burned children, physicians follow a more liberal transfusion strategy than the proposed in guidelines.
\end{abstract}

Keywords: Blood transfusion, Transfusion thresholds, Pediatric burn injury, Patient blood management, Pediatric, Red blood cells

\footnotetext{
* Correspondence: wittenme@uni-mainz.de

'Department of Anesthesiology, University Medical Centre of Johannes

Gutenberg University, Langenbeckstraße 1, 55131 Mainz, Germany

Full list of author information is available at the end of the article
}

(c) The Author(s). 2021 Open Access This article is licensed under a Creative Commons Attribution 4.0 International License, which permits use, sharing, adaptation, distribution and reproduction in any medium or format, as long as you give appropriate credit to the original author(s) and the source, provide a link to the Creative Commons licence, and indicate if changes were made. The images or other third party material in this article are included in the article's Creative Commons licence, unless indicated otherwise in a credit line to the material. If material is not included in the article's Creative Commons licence and your intended use is not permitted by statutory regulation or exceeds the permitted use, you will need to obtain permission directly from the copyright holder. To view a copy of this licence, visit http://creativecommons.org/licenses/by/4.0/ The Creative Commons Public Domain Dedication waiver (http://creativecommons.org/publicdomain/zero/1.0/) applies to the data made available in this article, unless otherwise stated in a credit line to the data. 


\section{Background}

Red blood cell (RBC) transfusion might be life-saving in severe cases of anemia in perioperative and critical care settings. However, in recent years, adverse effects of blood transfusion on postoperative morbidity and mortality have been observed [1-4]. In consequence, patient blood management (PBM) programs have been developed in order to optimize the utilization of blood components and thereby improve the clinical outcome and patient safety. After prospective clinical trials showed that it is safe to start transfusion at a lower hemoglobin $(\mathrm{Hb})$ threshold, restrictive transfusion practice was recommended with caution at higher risk of oxygen supply $[5,6]$. Current research focuses on establishing the adequate transfusion rules for patients. Current transfusion practice is not known for pediatric population, but surveys and clinical studies suggest that striking variability exists in perioperative pediatric RBC transfusion practice [7-9].

Reports of Serious Hazards of Transfusion (SHOT) show that the incidence of adverse events is higher in infants. In addition, in the recent SHOT report pediatric cases continue to be over-represented in several categories, particularly in under- and over-transfusion and in incorrect blood component transfusion [10]. Furthermore, children are supposed to be at higher risk for noninfectious adverse events like febrile nonhemolytic transfusion reaction, TACO (transfusion associated circulatory overload) and TRALI (transfusion related acute lung injury). Mortality associated with noninfectious risks is higher than in adults $[11,12]$. Few blood transfusion guidelines address blood transfusion in children and recommend a restrictive approach [13-16]. Pediatric patients with burn injury often require $\mathrm{RBC}$ transfusion during their hospital stay. As burned pediatric patients are immunosuppressed and RBC transfusion may affect the immune system [17], a restrictive approach in particular might prove beneficial for them [18]. In adults with burn injury, data from a prospective study suggest that the outcome of both the restrictive and liberal blood transfusion strategy is the same [19]. There is a lack of prospective studies on burned pediatric patients. Cohort studies examining the change of transfusion practice in burned children suggest that a restrictive transfusion policy does not have any adverse effect on patient outcome and may prove cost-effective. However, little is known about the current transfusion practice of pediatric population and their adherence to current guidelines.

\section{Methods}

This retrospective study was performed to evaluate the transfusion practice in children with burn injury, their predictive factors, and adherence to the German guidelines for blood transfusion. For this purpose, we reviewed all children younger than 8 years and who underwent surgery for burn injury from January 1, 2010 to January 1,
2015. The local ethics committee (Rhineland Palatine, Germany) had approved this study. Pre-, intra-, and postoperative transfusion data and other perioperative care data of these children were identified by screening their operation schedule, and subsequently, data were obtained by revising the children's patient charts. Transfusion, laboratory, application of catecholamines and other patient data were collected from the beginning to the end of hospital stay. Additionally, postoperative length of stay in intensive care unit (ICU) and overall length of stay in hospital were evaluated. Children with incomplete or lack of key information of their anesthesia protocol were excluded. The hemoglobin concentration $(\mathrm{Hb})$ before the first transfusion of RBC was compared with the proposed $\mathrm{Hb}$ triggers of the German transfusion guidelines for children older than 4 months [16] (Table 1). Transfusion thresholds have not changed with regard to $\mathrm{Hb}$ as per the German transfusion guideline during our study period and are still valid today.

For this purpose, children who had transfusion were classified into two groups: $\mathrm{Hb}$ value of children that needed catecholamines directly before or at the start of transfusion was compared with the $\mathrm{Hb}$ threshold for instable children $(10 \mathrm{~g} / \mathrm{dL})$. Hb values of transfused children that did not need catecholamines were compared with the threshold for stable children $(6 \mathrm{~g} / \mathrm{dL})$.

For categorical variables, absolute and relative frequencies were provided; median, minimum, and maximum were calculated. Potential influence of the explanatory covariates on the decision to transfuse was assessed by using logistic regression. We used multiple imputation (MI) for sensitivity analysis as potential explanatory variables for all patients had not been documented. MI was performed by SAS PROC MI, and the results were combined by SAS PROC MIANALYZE. We performed 10 imputations, and in order to impute missing values, we used transfusion, age, gender, operation procedure, American Society of Anesthesiologists' (ASA) classification, height, weight, duration of surgery, minimal $\mathrm{Hb}$, Quick, lactate, proportion of TBSA, postoperative length of stay, and length of stay in ICU. We used covariance analysis to assess the effect of transfusion on length of stay, adjusting for age, gender, minimal $\mathrm{Hb}$, proportion of TBSA, ASA, and operation procedure. Again, we

Table 1 Hemoglobin thresholds of the German guideline of blood transfusion for children

\begin{tabular}{ll}
\hline Patient criteria & $\begin{array}{l}\text { Lowest acceptable hemoglobin threshold } \\
\text { according to the German guidelines of } \\
\text { blood transfusion }\end{array}$ \\
\hline $\begin{array}{l}>4 \text { months } \\
\text { hemodynamically stable }\end{array}$ & $\mathbf{6 ~ g / d L}$ \\
$>4$ months & $10 \mathrm{~g} / \mathbf{d L}$ \\
hemodynamically instable & \\
\hline
\end{tabular}


performed both complete case (CC) and MI analyses. The results of the $C C$ were presented in the main paper, and the results of the MI were presented in supplementary materials.

Differences were noted in the circulatory parameters before and after transfusion using the t-test and Wilcoxon test. All tests were performed with exploratory intention; hence, $p$ values are descriptive in nature. Nevertheless, $\mathrm{p}$ values $<0.05$ were considered statistically significant..

\section{Results}

During the four-year period, a total of 152 patients were eligible for the study; however, 14 patients' charts were incomplete or with insufficient key information, thus 138 patients were analyzed. Of these 31 were transfused with RBCs, 18 of them additionally with fresh frozen plasma. One patient was only transfused postoperatively, whereas another patient's transfusion has started preoperatively and was going on intraoperatively, and the rest of patients were transfused intraoperatively. Cell saver was not used at all, and fibrinogen was given in 9 transfused and 3 non transfused children. Patient characteristics are shown in Table 2. Children without RBC transfusion had a median area of $10 \%$ TBSA, whereas children with transfusion had a median area of $30 \%$ TBSA (Table 2 and Fig. 1).

In the $\mathrm{CC}$ logistic regression analysis, we found that minimal $\mathrm{Hb}(\mathrm{OR}=0.48$ per $1 \mathrm{~g} / \mathrm{dl}$ in $\mathrm{Hb}, 95 \% \mathrm{CI}=[0.24$; $0.95], p=0.0343)$, length of surgery $(\mathrm{OR}=1.016$ per minute, 95\% $\mathrm{CI}=[1.003 ; 1.028], p=0.0150)$, and TBSA $(\mathrm{OR}=1.17$ per $\% \mathrm{TBSA}, 95 \% \mathrm{CI}=[1.05 ; 1.30], p=0.0056$ were associated with transfusion. Age, sex, ASA, and catecholamines did not show any association with transfusion (Table 3).

The outcome of the logistic regression analysis for predicting transfusion based on $\mathrm{MI}$ is similar to the $\mathrm{CC}$ analysis. Minimal $\mathrm{Hb}(\mathrm{OR}=0.48,95 \% \mathrm{CI}=[0.26 ; 0.90]$, $p=0.0230)$, length of surgery $(\mathrm{OR}=1.017$ per minute, $95 \% \mathrm{CI}=[1.005 ; 1.029], p=0.0063)$, and TBSA $(\mathrm{OR}=1.15$ per \% TBSA, 95\% CI $=[1.04 ; 1.28], p=0.0069)$ are associated with the transfusion, while the other covariates do not exhibit notable association with transfusion (an Additional file 1 shows this in more detail in Table 3b).

Neither CC nor MI found an association of transfusion and length of stay after adjusting for other variables, which are likely to be associated with length of stay. Length of stay was mainly influenced by TSBA $(+1.38$ days per \% ([CC]), $p<0.0001 ;+1.08$ days per \% ([MI]), $p<0.0001)$, age $(+0.21$ days per month ([CC]), $p=0.0206$;

Table 2 Characteristics of children and surgery

\begin{tabular}{|c|c|c|c|c|}
\hline Patient characteristics & $\begin{array}{l}\text { All children } \\
n=138\end{array}$ & $\begin{array}{l}\text { Children with } \\
\text { transfusion of RBC } \\
n=31\end{array}$ & $\begin{array}{l}\text { Children without } \\
\text { transfusion of RBC } \\
n=107\end{array}$ & $p$-value* \\
\hline $\begin{array}{l}\text { Gender (years) } \\
N=138\end{array}$ & $\begin{array}{l}\text { m: } 83(60 \%) \\
\text { f: } 55(40 \%)\end{array}$ & $\begin{array}{l}\text { m: } 23(74 \%) \\
f: 8(26 \%)\end{array}$ & $\begin{array}{l}\text { m: } 60(56 \%) \\
f: 47(44 \%)\end{array}$ & 0.0952 \\
\hline $\begin{array}{l}\text { Age (months) } \\
N=138\end{array}$ & $21(9-101)$ & $19(12-93)$ & $21(9-101)$ & 0.5568 \\
\hline Weight $(\mathrm{kg}) n=136(31 / 105)^{* *}$ & $12(7-30)$ & $12(9.5-30)$ & $12(7-30)$ & 0.7463 \\
\hline \multirow{4}{*}{$\begin{array}{l}\text { ASA Classification } \\
N=130(29 / 101)\end{array}$} & 1: $34(26 \%)$ & 1: $4(14 \%)$ & 1: 30 (30\%) & \multirow[t]{4}{*}{0.0155} \\
\hline & 2: $72(55 \%)$ & 2: $14(48 \%)$ & 2: 58 (57\%) & \\
\hline & 3: $16(12 . \%)$ & $3: 7(24 \%)$ & 3: 9 (9\%) & \\
\hline & 4: $8(6 \%)$ & 4: $4(14 \%)$ & 4: 4 (4\%) & \\
\hline Prothrombin time $n=44(17 / 27)$ & $97 \%(40-125 \%)$ & $91 \%(40-124 \%)$ & $100 \%(64-125 \%)$ & 0.1656 \\
\hline Lactate level $n=47(28 / 19)$ & $1.0(0.3-4.8) \mathrm{g} / \mathrm{dL}$ & $1.0(0.3-4.8) \mathrm{g} / \mathrm{dL}$ & $1.0(0.3-2.8) \mathrm{g} / \mathrm{dL}$ & 0.8708 \\
\hline Proportion of TBSA & $15 \%(1-40)$ & $30 \%(4-40)$ & $10 \%(1-40)$ & $<0.0001$ \\
\hline $\begin{array}{l}\text { Length of surgery (min) } \\
N=138\end{array}$ & $72(5-475)$ & $210(28-475)$ & $47(5-400)$ & $<0.0001$ \\
\hline $\begin{array}{l}\text { Minimal hemoglobin }(\mathrm{g} / \mathrm{dL}) \\
N=91(31 / 60)\end{array}$ & $9.6(6.3-13.8)$ & $8(6.3-11.3)$ & $10.7(7.0-13.8)$ & $<0.0001$ \\
\hline $\begin{array}{l}\text { Postoperative length of hospital } \\
\text { stay (days) } n=138\end{array}$ & $11(1-94)$ & $41(9-94)$ & $8(1-91)$ & $<0.001$ \\
\hline catecholamines $N=138$ & $\begin{array}{l}\text { Yes: } 14(10 \%) \\
\text { No: } 124(90 \%)\end{array}$ & $\begin{array}{l}\text { Yes: } 8(26 \%)^{a} \\
\text { No: } 23(74 \%)\end{array}$ & $\begin{array}{l}\text { Yes: } 6(6 \%)^{b} \\
\text { No: } 101(94 \%)\end{array}$ & 0.0032 \\
\hline
\end{tabular}

TBSA total burned body surface area, ASA American Society of Anesthesiologists, $m$ male, $f$ female. Values are absolute numbers (proportion) or median (minimum-maximum)

a applied directly before or while transfusion bapplied during the hospital stay

${ }^{*} p$ values for comparison between children with and without transfusion

**Numbers in brackets give numbers of children with and without transfusion for whom measurement is available 


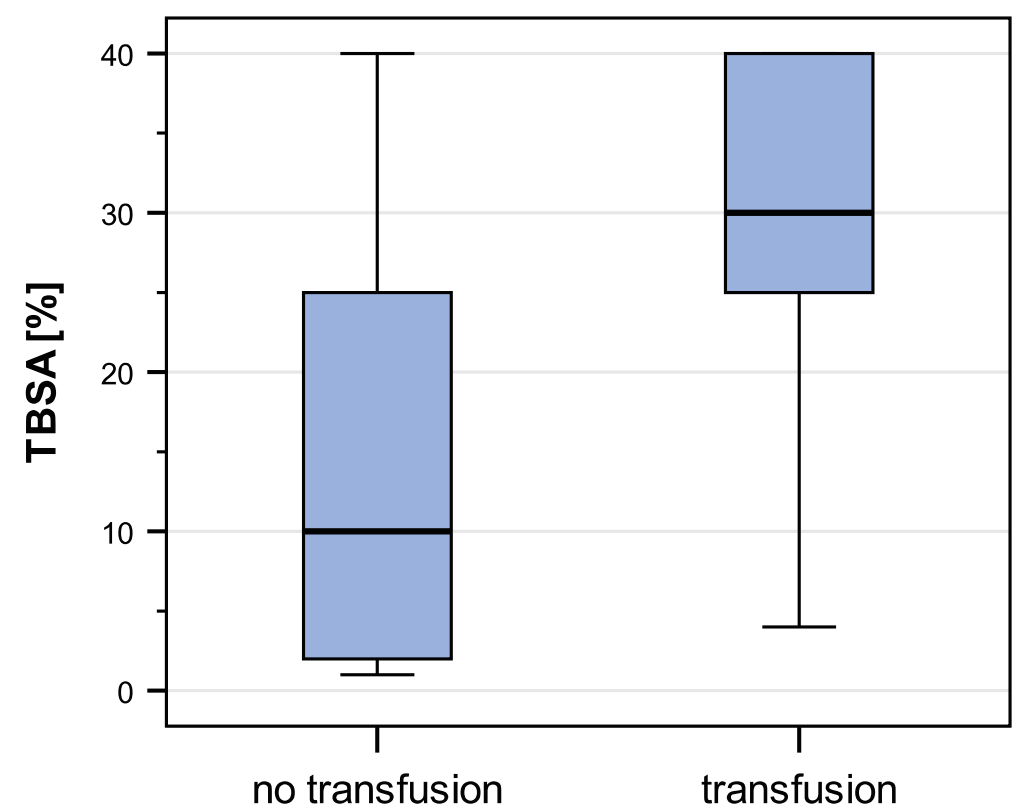

Fig. 1 Total body surface area burned (TBSA) influences the probability of transfusion with red blood cells. Children with burn injury without transfusion of RBC had a median TBSA of 10\% (minimum-maximum 1-40) and children with transfusion had 30\% $(4-40)(p<0.0001)$

+0.19 days per month $([\mathrm{MI}]), p=0.0026)$, and administering of catecholamines $(+14.3$ days $([\mathrm{CC}]), p=0.0118 ;+$ 13.24 ([MI]), $p=0.0080)$. Necrectomy influenced length of stay in the MI $(+14$ days, $p=0.0146)$, but not in the CC (+ 8.43 days, $p=0.2353)$.

Hemoglobin concentration was measured in 91 children (31 transfused/60 non-transfused) and compared with the German transfusion guidelines (Table 2 and Fig. 2). The median minimal hemoglobin concentration of nontransfused children was $10.7 \mathrm{~g} / \mathrm{dL}$ and that of transfused children was $8.0 \mathrm{~g} / \mathrm{dL}$. Hb was collected from every child before transfusion, but not controlled in five children after transfusion. The decision to transfuse was too restrictive in $7 / 31$ ( $23 \%$, all of them were children with catecholamines), too liberal in $23 / 31(74 \%)$, and correctly in one case (3\%) according to the German guidelines. The median increase of hemoglobin was $1.3 \mathrm{~g} / \mathrm{dL}$; the median transfused volume of RBC was 13,6 ml/kg (4.2-66.7 min-max). Transfusion of $\mathrm{RBC}$ had a measurable effect on circulatory parameters like $\mathrm{Hb}$, heart rate, and SAP (Table 4).

Table 3 Association of explanatory factors on transfusion, complete case analysis

\begin{tabular}{llll}
\hline & Odds Ratio & & \\
\cline { 2 - 3 } & Point estimate & $\mathbf{9 5 \%}$ Confidence interval & $\mathbf{p}$ \\
\hline Age (per year) & 0.99 & {$[0.95 ; 1.03]$} & 0.6389 \\
Gender (female vs male) & 0.45 & {$[0.03 ; 5.94]$} & 0.5445 \\
TBSA (per \%) & 1.17 & {$[1.05 ; 1.30]$} & $\mathbf{0 . 0 0 5 6}$ \\
ASA: 2 vs 1 & 0.37 & {$[0.02 ; 6.34]$} & 0.8162 \\
ASA: 3 vs 1 & 0.11 & {$[0.003 ; 5.09]$} & 0.2692 \\
ASA: 4 vs 1 & 0.25 & {$[0.01 ; 8.86]$} & 0.7697 \\
Length of surgery (per minute) & 1.016 & {$[1.003 ; 1.028]$} & $\mathbf{0 . 0 1 5 0}$ \\
Minimal hemoglobin (per g/dL) & 0.48 & {$[0.24 ; 0.95]$} & $\mathbf{0 . 0 3 4 3}$ \\
Catecholamines & 1.27 & {$[0.15 ; 10.53]$} & 0.8243 \\
Necrectomy & 0.82 & {$[0.03 ; 22.35]$} & 0.9502 \\
Skin harvesting and grafting & 1.33 & {$[0.15 ; 11.98]$} & 0.8011 \\
Change of dressings & 1.02 & {$[0.04 ; 27.19]$} & 0.9919 \\
Wound refreshment & 1.33 & {$[0.06 ; 31.28]$} & 0.8614 \\
\hline
\end{tabular}




\subsubsection{1}

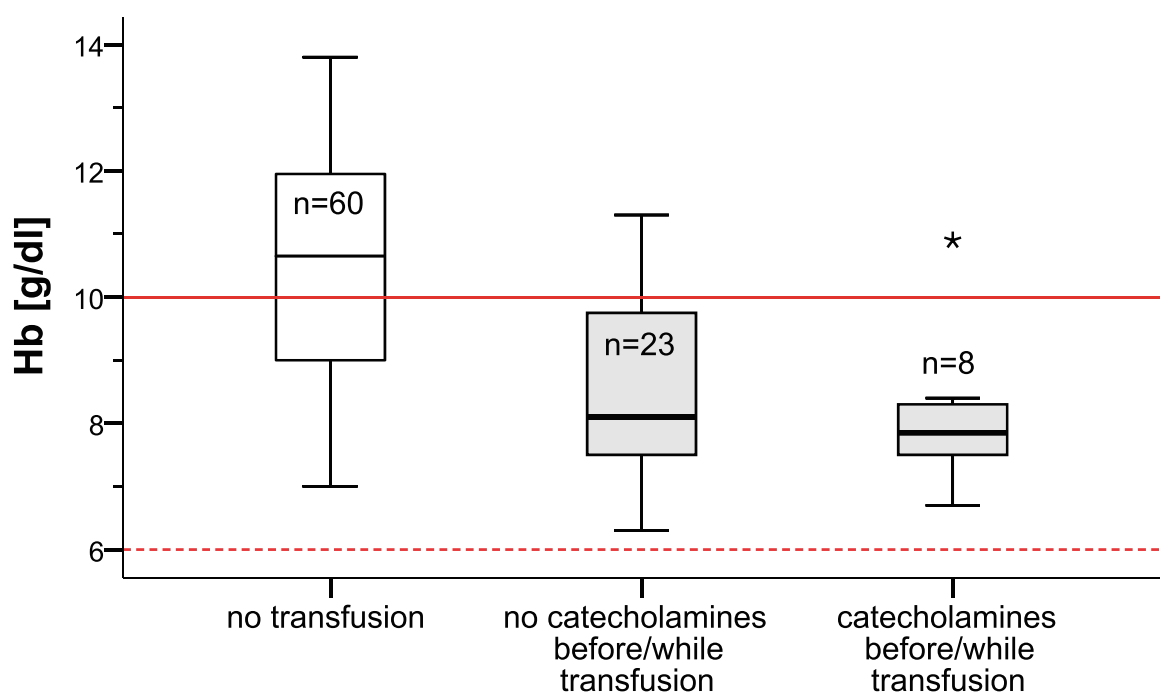

Fig. 2 Practice of transfusion compared to the German guidelines of blood transfusion. The examined hemoglobin concentrations (Hbs) are the minimal Hbs during hospital stay (for children who did no receive red blood cells $[R B C s]$ ) or the measured Hbs before transfusion of RBCs (for children who received transfusion). The Hb-threshold lines (red) represent the Hb-thresholds of the German guideline of blood transfusion for stable $(6 \mathrm{~g} / \mathrm{dl})$ or instable $(10 \mathrm{~g} / \mathrm{dl})$ children $>4$ months [16]. The diagram shows that all hemodynamically stable children were transfused at hemoglobin triggers higher than recommended in the German guidelines. Transfused children that received catecholamines were transfused too restrictive according to the German guidelines. Overall the decision to transfuse was too liberally in 74 , too restrictive in $23 \%$ and in $3 \%$ adequate according to the German guidelines

\section{Discussion}

In our study, TBSA, length of surgery, and $\mathrm{Hb}$ influenced the transfusion rate in burned children. Length of stay was not influenced by RBC transfusion. According to the German transfusion guidelines, more than half of the children were transfused too liberally.

Non-transfused children had a median area of $10 \%$ TBSA, whereas transfused children had a median area of $30 \%$ TBSA. A multicenter retrospective study in a mixed population of adults and children with burn injury found that $75 \%$ of patients with TBSA $>20 \%$ received blood transfusion [20]. Another observational study evaluating predictive factors for blood transfusion in adults and children found TBSA $>20 \%$ is a useful predictor for blood transfusion [21]. Only few data are available to evaluate the association between TBSA and transfusion in an exclusively pediatric collective study like ours. Interestingly, another retrospective study found in transfused children with burn injury a mean TBSA of 29 to $31 \%$. This corresponds to our findings. Information of TBSA of non-transfused children were not evaluated in this study [22]. Another retrospective cohort study evaluated the effects of a change to a restrictive blood transfusion protocol in acute pediatric burn injuries. Children who received blood had a mean TBSA of $45 \%$ (before the protocol change) and 43\% (after the protocol change), respectively. TBSA of children who did not receive blood transfusion was not described [23].

Table 4 Effects of red blood cell transfusion on circulatory parameters in children with burn injury

\begin{tabular}{llll}
\hline Measured parameters & Before transfusion & After transfusion & p-value \\
\hline Hemoglobin concentration & $8.0 \mathrm{~g} / \mathrm{dL}$ & $9.8 \mathrm{~g} / \mathrm{dL}$ & $\mathrm{p}<0.001$ \\
& $(6.3-11.3)$ & $n=26$ & \\
Increase of hemoglobin after transfusion & $\mathrm{n}=31$ & $1.3(-1.1-5.0)$ \\
& & $n=26$ & $120 / \mathrm{min}$ \\
Heart rate & $125 / \mathrm{min}$ & $85-155)$ & $p=0.017$ \\
Systolic blood pressure & $(90-160)$ & $93 \mathrm{mmHg}$ & $p<0.001$ \\
& $80 \mathrm{mmHg}$ & $(80-115)$ & \\
\hline
\end{tabular}


In our study, the length of surgery also correlated with the transfusion rate. Obviously, this can be explained by the fact that surgeons need more time for larger TBSA.

Age did not influence transfusion rate. This statement contrasts the other finding that suggests younger age is a risk factor for transfusion. In an observational study examining transfusion practice in children older than 28 days who underwent surgery in different hospitals was found that younger age (29 days to 2 years) among other factors was a preoperative variable associated with increased odds of having an intraoperative or postoperative $\mathrm{RBC}$ transfusion [7]. A recently published register study in pediatric patients undergoing complex cranial vault reconstruction identified that age less than 24 months as one of the factors for increased RBC transfusion [24].

Length of stay was mainly influenced by whether it was an emergency procedure, TSBA, and age, not by the transfusion rate. Prospective studies examining this subject in children are rare. Lacroix et al. compared in a prospective, multicenter study in stable, critically ill children in ICU restrictive with liberal RBC transfusion strategies and found no difference in length of stay in ICU [25]. Retrospective studies in burned children with protocol changes showed that days of hospitalization were less [23] or the same [22] after the change. Prospective data investigating the impact of transfusion on length of total hospital stay in this special population are to the best of our knowledge not available.

In our study, transfusion had a measurable effect on heart rate and systolic blood pressure; however, the effect is small, thus we cannot exclude that this effect is due to other factors such as catecholamines.

Our study evaluated the minimal hemoglobin concentration of transfused and non-transfused children during their hospital stay. Lower hemoglobin concentration was associated with RBC transfusion. The median minimal hemoglobin concentration of non-transfused children was $10.7 \mathrm{~g} / \mathrm{dL}$, and $8 \mathrm{~g} / \mathrm{dL}$ before receiving $\mathrm{RBC}$. The German guidelines for blood transfusion recommend a threshold of 6 to $7 \mathrm{~g} / \mathrm{dL}$ (hemodynamically stable) and $10 \mathrm{~g} / \mathrm{dL}$ (hemodynamically unstable) for children older than 4 months with active bleeding [16]. These guidelines do not specifically address children with burn injury, thus special $\mathrm{Hb}$ thresholds for this collective are not available in a guideline because available prospective randomized data of critically ill children without acute blood loss cannot be fully be applied to pediatric patients with burn injury [26] International guidelines propose lower guidelines for children with bleeding, but they do not specify $\mathrm{Hb}$ thresholds for unstable children because of insufficient data [13, 14]. $74 \%$ of the children were transfused too liberally. Most of the too liberal transfusions happened in children that did not receive catecholamines. The reason for this could be the threshold of $6 \mathrm{~g} / \mathrm{dL}$ for stable children is a very restrictive approach that is not yet practiced. In a British multicenter observational study of RBC transfusion practice in children with a median age of 5 years, the median pre-transfusion hemoglobin was $7.9 \mathrm{~g} / \mathrm{dL}$ [8]. On the other hand, the small increase of $\mathrm{Hb}$ after transfusion in our study is a restrictive approach that corresponds to the recommendation that post-transfusion $\mathrm{Hb}$ should not be $>2 \mathrm{~g} / \mathrm{dl}$ above the transfusion threshold [27]. Unfortunately, database for risks or benefits of a restrictive transfusion approach versus a liberal one in pediatric patients is very small. One prospective landmark study of Lacroix et al. showed that restrictive transfusion strategy in stable critically ill children does not increase adverse events [25]. A few clinical studies have examined blood transfusion effects retrospectively [28-30]. Similar to adults, they showed increased incidence of 30 days mortality, postoperative infections, and correlation between the volume of RBC transfused and the incidences of adverse outcomes [30], length of mechanical ventilation, and length of ICU stay $[28,29]$.

For the subgroup of children with burn injury a recent study showed that restrictive blood transfusion with a hemoglobin threshold of $7 \mathrm{~g} / \mathrm{dL}$ protocol in acute pediatric burn care is safe, may reduce medical risks, and lower economic burden [23]. Transfusion-related immunomodulation (TRIM) is one of the effects of allogeneic blood transfusion. To what extent these immunomodulatory effects alter clinical outcomes remains controversial [31]. Children with burn injury are immunosuppressed, and massive transfusion could put them at risk for TRIM, transfusion-related graft-versushost reaction and enhanced allograft survival. However, these effects are yet to be examined in pediatric population. Retrospective studies showed a potentially higher risk for the development of sepsis [18] In a prospective study among adults, wound healing, mortality and infection did not differ between restrictive and liberal transfused adult patients with burn injury [19].

Children with burn injury are immunosuppressed. Therefore, the risk of this complication should be minimized. In a retrospective cohort study, children with burn injury of $60 \%$ TBSA and concomitant inhalation injury were more likely to develop sepsis after transfusion of high amounts of blood products [18]. Hence, children with burn injury could benefit from a restrictive transfusion practice in particular. Apart from that restrictive transfusion practice minimizes other adverse effect of transfusion in children like hyperkalemia [26], TACO, febrile hemolytic transfusion reactions and incorrect blood component use [11, 12]. Indeed, prospective studies in burned children examining the effects and safety of restrictive versus liberal regimen are lacking. In summary, the transfusion practice in the examined 
collective reflects that children are transfused more liberally than possible or recommended. In addition, PBM strategies helping to avoid transfusion were not (cell saver) or poorly (fibrinogen or tranexamic acid (TXA)) applied. Recommendations for the use of TXA, fibrinogen, and cell saver in pediatric patients have been made during the last 10 years $[11,13,15,32,33]$; however data whether these strategies are really practiced in pediatric perioperative transfusion practice is insufficient. Therefore, this study suggests a possible gap between recommendation and reality.

\section{Conclusion}

In this retrospective collective, the amount of TBSA, $\mathrm{Hb}$, and length of surgery influenced the transfusion rate. Age and length of stay were not influenced by RBC transfusion. According to the German guidelines of blood transfusion, most of the children were infused too liberally, indicating that restrictive hemoglobin triggers are not yet implemented in clinical practice of pediatric anesthesia in pediatric burn care.

\footnotetext{
Abbreviations

ASA: American Society of Anesthesiologists; CC: Complete case analysis; $\mathrm{Hb}$ : Hemoglobin concentration; LOS: Length of stay; MI: Multiple imputation; OR: Odds ratio; RBC: Red blood cell; SAP: Systolic arterial pressure; TBSA : Total body surface area burned
}

\section{Supplementary Information}

The online version contains supplementary material available at https://doi. org/10.1186/s12871-021-01336-3.

Additional file 1: Table 3b supplement. Characteristics of children

and surgery using multiple imputation.

\section{Acknowledgments}

Not applicable.

\section{Authors' contributions}

EW designed the study, analyzed the data and wrote the manuscript. KA collected and analyzed the data. IS, EG, MK and TK analyzed the date and wrote parts of the manuscript. NP interpreted the data and wrote parts of the manuscript. Parts of the data presented in this manuscript will be parts of the doctorate theses of KA. All authors have read and approved the manuscript, and ensure that this is the case.

\section{Funding}

No funding. Open Access funding enabled and organized by Projekt DEAL.

\section{Availability of data and materials}

The datasets used and/or analyzed during this study are available from the corresponding author on reasonable request

\section{Declarations}

Ethics approval and consent to participate

The local Ethical Committee of the Medical Association of the Rhineland Palatine state (Germany, Chairperson: Andrea Wagner, MD) approved this study by letter in October 2014.

\section{Consent for publication}

Not applicable.

\section{Competing interests}

The authors declare that they have no competing interests.

\section{Author details}

${ }^{1}$ Department of Anesthesiology, University Medical Centre of Johannes Gutenberg University, Langenbeckstraße 1, 55131 Mainz, Germany.

${ }^{2}$ Department of Anesthesiology and Intensive Care, Catholic Clinical Centre, Mainz, Germany. ${ }^{3}$ Institute of Medical Biostatistics, Epidemiology and Informatics, University Medical Centre of Johannes Gutenberg University, Mainz, Germany. ${ }^{4}$ Department of Pediatric Surgery, University Medical Centre of Johannes Gutenberg University, Mainz, Germany.

Received: 26 June 2020 Accepted: 9 April 2021

Published online: 15 April 2021

References

1. Marik PE, Corwin HL. Efficacy of red blood cell transfusion in the critically ill: a systematic review of the literature. Crit Care Med. 2008;36(9):2667-74. https://doi.org/10.1097/CCM.0b013e3181844677.

2. Ferraris VA, Hochstetler M, Martin JT, Mahan A, Saha SP. Blood transfusion and adverse surgical outcomes: the good and the bad. Surgery. 2015;158(3): 608-17. https://doi.org/10.1016/j.surg.2015.02.027.

3. Rohde JM, Dimcheff DE, Blumberg N, Saint S, Langa KM, Kuhn L, et al. Health care-associated infection after red blood cell transfusion: a systematic review and meta-analysis. Jama. 2014;311(13):1317-26. https:// doi.org/10.1001/jama.2014.2726.

4. Anthes E. Evidence-based medicine: save blood, save lives. Nature. 2015; 520(7545):24-6. https://doi.org/10.1038/520024a.

5. Hovaguimian F, Myles PS. Restrictive versus Liberal transfusion strategy in the perioperative and acute care settings: a context-specific systematic review and meta-analysis of randomized controlled trials. Anesthesiology. 2016;125(1):46-61. https://doi.org/10.1097/ALN.0000000000001162.

6. Mazer CD, Whitlock RP, Fergusson DA, Belley-Cote E, Connolly K, Khanykin B, et al. Six-month outcomes after restrictive or Liberal transfusion for cardiac surgery. N Engl J Med. 2018;379(13):1224-33. https://doi.org/10.1056/ NEJMoa1808561.

7. Stey AM, Vinocur CD, Moss RL, Hall BL, Cohen ME, Kraemer K, et al. Variation in intraoperative and postoperative red blood cell transfusion in pediatric surgery. Transfusion. 2016;56(3):666-72. https://doi.org/10.1111/trf.13479.

8. New HV, Grant-Casey J, Lowe D, Kelleher A, Hennem S, Stanworth SJ. Red blood cell transfusion practice in children: current status and areas for improvement? A study of the use of red blood cell transfusions in children and infants. Transfusion. 2014;54(1):119-27. https://doi.org/10.1111/trf.12313.

9. Wittenmeier E, Troeber C, Zier U, Schmidtmann I, Pirlich N, Becke K, et al. Red blood cell transfusion in perioperative pediatric anesthesia: a survey of current practice in Germany. Transfusion. 2018;58(7):1597-605. https://doi. org/10.1111/trf.14581.

10. Group. SNEDPeaobotSHoTSS. The 2019 Annual SHOT Report (2020). 2020.

11. Lavoie J. Blood transfusion risks and alternative strategies in pediatric patients. Paediatr Anaesth. 2011;21(1):14-24. https://doi.org/10.1111/j.14609592.2010.03470.x

12. Stainsby D, Jones H, Wells AW, Gibson B, Cohen H, Group SS. Adverse outcomes of blood transfusion in children: analysis of UK reports to the serious hazards of transfusion scheme 1996-2005. Br J Haematol. 2008; 141(1):73-9. https://doi.org/10.1111/j.1365-2141.2008.07022.x.

13. Kozek-Langenecker SA, Ahmed AB, Afshari A, Albaladejo P, Aldecoa C, Barauskas $G$, et al. Management of severe perioperative bleeding: guidelines from the European Society of Anaesthesiology: first update 2016. Eur J Anaesthesiol. 2017;34(6):332-95. https://doi.org/10.1097/EJA. 0000000000000630.

14. Valentine SL, Bembea MM, Muszynski JA, Cholette JM, Doctor A, Spinella PC, et al. Consensus recommendations for RBC transfusion practice in critically ill children from the pediatric critical care transfusion and Anemia expertise initiative. Pediatric Crit Care Med. 2018;19(9):884-98. https://doi.org/10.1097/ PCC.0000000000001613.

15. Australian National Health Authority's Patient Blood Management Guidelines; Module 6 Neonatal and pediatric. https://www.blood.gov.au/ pbm-module-6.

16. Cross-sectional Guidelines for Therapy with Blood Components and Plasma Derivatives-amended edition 2020. https://www.bundesaerztekammer.de/ fileadmin/user_upload/downloads/pdf-Ordner/MuE/Querschnitts- 
Leitlinien_BAEK_zur_Therapie_mit_Blutkomponenten_und_Plasmaderiva ten_-Gesamtnovelle_2020.pdf.

17. Muszynski JA, Spinella PC, Cholette JM, Acker JP, Hall MW, Juffermans NP, et al. Transfusion-related immunomodulation: review of the literature and implications for pediatric critical illness. Transfusion. 2017;57(1):195-206. https://doi.org/10.1111/trf.13855.

18. Jeschke MG, Chinkes DL, Finnerty CC, Przkora R, Pereira CT, Herndon DN Blood transfusions are associated with increased risk for development of sepsis in severely burned pediatric patients. Crit Care Med. 2007;35(2):57983. https://doi.org/10.1097/01.CCM.0000253812.09236.98.

19. Palmieri TL, Holmes JH, Arnoldo B, Peck M, Potenza B, Cochran A, et al. Transfusion requirement in burn care evaluation (TRIBE): a multicenter randomized prospective trial of blood transfusion in major burn injury. Ann Surg. 2017;266(4):595-602. https://doi.org/10.1097/SLA.0000000000002408.

20. Palmieri TL, Caruso DM, Foster KN, Cairns BA, Peck MD, Gamelli RL, et al. Effect of blood transfusion on outcome after major burn injury: a multicenter study. Crit Care Med. 2006;34(6):1602-7. https://doi.org/10.1097/ 01.CCM.0000217472.97524.0E.

21. Kilyewala C, Alenyo R, Ssentongo R. Determinants and time to blood transfusion among thermal burn patients admitted to Mulago hospital. BMC Res Notes. 2017;10(1):258. https://doi.org/10.1186/s13104-017-2580-2.

22. Palmieri TL, Lee T, O'Mara MS, Greenhalgh DG. Effects of a restrictive blood transfusion policy on outcomes in children with burn injury. J Burn Care Res. 2007;28(1):65-70. https://doi.org/10.1097/BCR.0B013E31802C895E.

23. Voigt CD, Hundeshagen G, Malagaris I, Watson K, Obiarinze RN, Hasanpour $\mathrm{H}$, et al. Effects of a restrictive blood transfusion protocol on acute pediatric burn care: transfusion threshold in pediatric burns. J Trauma Acute Care Surg. 2018;85(6):1048-54. https://doi.org/10.1097/TA.0000000000002068.

24. Fernandez PG, Taicher BM, Goobie SM, Gangadharan M, Homi HM, Kugler $J A$, et al. Predictors of transfusion outcomes in pediatric complex cranial vault reconstruction: a multicentre observational study from the pediatric craniofacial collaborative group. Canadian journal of anaesthesia $=. \mathrm{J}$ Canadien d'anesthesie. 2019;66(5):512-26. https://doi.org/10.1007/s12630-01 9-01307-w.

25. Lacroix J, Hebert PC, Hutchison JS, Hume HA, Tucci M, Ducruet T, et al. Transfusion strategies for patients in pediatric intensive care units. N Engl J Med. 2007;356(16):1609-19. https://doi.org/10.1056/NEJMoa066240.

26. Palmieri TL. Children are not little adults: blood transfusion in children with burn injury. Burns Trauma. 2017;5:24.

27. New HV, Berryman J, Bolton-Maggs PH, Cantwell C, Chalmers EA, Davies T, et al. Guidelines on transfusion for fetuses, neonates and older children. $\mathrm{Br} J$ Haematol. 2016;175(5):784-828. https://doi.org/10.1111/bjh.14233.

28. Redlin M, Kukucka M, Boettcher W, Schoenfeld H, Huebler M, Kuppe $H$, et al. Blood transfusion determines postoperative morbidity in pediatric cardiac surgery applying a comprehensive blood-sparing approach. J Thorac Cardiovasc Surg. 2013;146(3):537-42. https://doi.org/10.1016/j. jtcvs.2012.09.101.

29. Kneyber MC, Hersi MI, Twisk JW, Markhorst DG, Plotz FB. Red blood cell transfusion in critically ill children is independently associated with increased mortality. Intensive Care Med. 2007;33(8):1414-22. https://doi. org/10.1007/s00134-007-0741-9.

30. Goobie SM, DiNardo JA, Faraoni D. Relationship between transfusion volume and outcomes in children undergoing noncardiac surgery. Transfusion. 2016;56(10):2487-94. https://doi.org/10.1111/trf.13732.

31. Carson JL, Triulzi DJ, Ness PM. Indications for and adverse effects of red-cell transfusion. N Engl J Med. 2017;377(13):1261-72. https://doi.org/10.1056/ NEJMra1612789.

32. Goobie SM, Haas T. Perioperative bleeding management in pediatric patients. Curr Opin Anaesthesiol. 2016;29(3):352-8. https://doi.org/10.1097/A CO.0000000000000308

33. Goobie SM, Gallagher T, Gross I, Shander A. Society for the advancement of blood management administrative and clinical standards for patient blood management programs. 4th edition (pediatric version). Paediatr Anaesth. 2019;29(3):231-6. https://doi.org/10.1111/pan.13574.

\section{Publisher's Note}

Springer Nature remains neutral with regard to jurisdictional claims in published maps and institutional affiliations.

Ready to submit your research? Choose BMC and benefit from:

- fast, convenient online submission

- thorough peer review by experienced researchers in your field

- rapid publication on acceptance

- support for research data, including large and complex data types

- gold Open Access which fosters wider collaboration and increased citations

- maximum visibility for your research: over $100 \mathrm{M}$ website views per year

At BMC, research is always in progress.

Learn more biomedcentral.com/submissions 